of a comprehensive handbook of British seaweeds. This work was continued after her marriage to Mr. W. C. F. Newton, who was cytologist at the John Innes Horticultural Institution. Following the untimely death of Mr. Newton in 1927, she became lecturer in botany at Aberystwyth and was appointed to the chair in 1930. She was president of Section K of the British Association in 1949, president of the British Phycological Society (1955-57), and while still in charge of the Department of Botany, held the offices of vice-principal and acting principal of the University College of Wales. Prof. Newton has had a distinguished career at Aberystwyth, where she continued the tradition for research on algæe estab. lished by the late Prof. Lloyd-Williams. Recently she has developed a fine botanical garden on the new College site. This will be invaluable when the new Department of Botany, which she has also planned, is completed.

Prof. P. F. Wareing

Dr. P. F. Wareing, senior lecturer in the Depart. ment of Botany of the University of Manchester, has been appointed to succeed Prof. Newton at Aberyst. wyth. Dr. Wareing was educated at Birkbeck College and Chelsea Polytechnic, London, while working as a Civil servant, and graduated with honours in botany in 1936. After service as a tele-communications officer during the Second World War, he was appointed assistant lecturer and later lecturer in the Department of Botany at Bedford College, London. In 1950 he moved to the University of Manchester, where he was appointed senior lecturer in 1956. Since 1947 Dr. Wareing has contributed to many important problems in the field of developmental physiology and in particular on the photo-periodic and chemical control of various growth processes. For this work he was awarded the degree of D.Sc.

Psychology at The Queen's University, Belfast :

Prof. G. Seth

Dr. George Seth, who has been appointed to the newly created chair of psychology at The Queen's University, Belfast, had already built up there a small but very active Department. Its research output during the past few years has been considerable, and its graduates are already making a worth-while contribution to British psychology. Dr. Seth graduated B.Ed. from the University of Edinburgh in 1930, and thus belongs to the golden age of that degree, when Sir Godfrey Thomson and Prof. James Drever, senior, turned out year after year students who went on to distinguish themselves in education and psychology. Dr. Seth is in fact the eleventh such graduate to be appointed to a university chair. Dr. Seth went up to the University of Edinburgh from the Royal High School, and took his M.A. with honours in English literature. He remained on the staff at Edinburgh, carrying out research for the Ph.D. degree. His thesis was published in 1935 as part of the important study, "Speech in Childhood: its Development and Disorders", by George Seth and Douglas Guthrie. From Edinburgh, Dr. Seth went in 1935 to be lecturer in the Department of Education, University College, Cardiff, where he remained until 1946. In addition to his teaching work, he was psychologist in the Cardiff Child Guidance Clinic, and during 1941-45 psychologist-in-charge of the Psychological Service for Difficult Children (Government Education Scheme) under the Welsh Board of Health. In 1946 he went to take charge of the newly founded Department of
Psychology at Belfast. There he has built up a well-balanced teaching and research programme, which has moved out from its beginnings in the vicinity of education to cover the whole psychological field from the experimental to the social boundaries, with applied work in the industrial and clinical as well as the educational fields. The newly created chair does no more than recognize in a fitting way the existence at Belfast of a Department of Psychology well able to hold its own with its older counterparts anywhere in Great Britain.

\section{Control of Research Programmes in the Department of Scientific and Industrial Research}

THE Council for Scientific and Industrial Research has announced a change in organization affecting the Department of Scientific and Industrial Research laboratories: small steering committees are being set up to bear responsibility for the research programmes at the new Warren Spring Laboratory, at Stevenage, and at the recently renamed National Chemical Laboratory, at Teddington (Nature, 182, $156,225 ; 1958)$. Formerly research boards, which the steering committees now replace, were responsible to the Research Council, but there was not necessarily any common membership. Under the new arrangement the steering committees are full committees of the Research Council and there will be a direct link between the two bodies, because the chairmen of the committees are members of the Council. In addition to the chairman there will be four members of each committee: two from industry with experience in research management, the secretary of the Department of Scientific and Industrial Research, and the director of the laboratory concerned. The industrial members of the Warren Spring Laboratory steering. committee are Dr. R. Holroyd (deputy chairman of Imperial Chemical Industries, Ltd.) and Mr. D. A. Oliver (director of research of the B.S.A. Group Research Centre). The chairman is Sir Harry Jephcott, who is chairman of the Research Council and chairman of Glaxo Laboratories, Ltd. The industrial members of the National Chemical Laboratory steering committee, which will assume responsibility from October 1, will be Dr. F. Roffey (research and personnel director of the Distillers Co., Ltd.) and Mr. B. Topley (director of development of Albright and Wilson, Ltd.). The chairman will be Prof. C. E. H. Bawn, of the University of Liverpool.

\section{Science Centre Scheme}

IN a written answer to Lord Bridgeman's request for a statement about the plans for a Science Centre and the reconstruction of the Patent Office, Lord Hailsham said in the House of Lords on July 30 that the Ministry of Works is negotiating for the lease of the site on the South Bank which was designated under the Science Centre scheme for the Patent Office, and it is intended to start building within the next five years. As originally proposed, this building will be designed to accommodate, in addition to the Patent Office, a new National Reference Library of Science and Invention, built up from the existing Patent Office Library. A further review of the original scheme to provide accommodation for the scientific learned societies, at present housed in Burlington House and elsewhere, on a site adjoining that which has now been leased has shown that the needs of the Royal Society and of the other scientific learned societies at present in Burlington House can, for some time to come, be met more satisfactorily in that 